\title{
Intrauterine deaths: challenges faced in developing countries
}

\author{
Neha Gupta*, Nimmi Chutani
}

Department of Obstetrics and Gynecology, School of Medical Sciences and Research, Knowledge Park 3 , Greater Noida, India

Received: 10 October 2013

Accepted: 27 October 2013

\author{
*Correspondence: \\ Dr. Neha Gupta, \\ E-mail: docnehanigam@gmail.com
}

(C) 2013 Gupta $\mathrm{N}$ et al. This is an open-access article distributed under the terms of the Creative Commons Attribution Non-Commercial License, which permits unrestricted non-commercial use, distribution, and reproduction in any medium, provided the original work is properly cited.

\begin{abstract}
Background: Reasons for intrauterine deaths differ in studies from different geographical areas. This study was done to determine common reasons for intrauterine deaths in Northern India, representing population from majority of developing world.

Methods: Retrospective study was done from Jan 2010 to April 2013, and files and records reviewed to determine reasons and other data of females with intrauterine deaths.

Results: Most common reasons for intrauterine deaths were prolonged/ obstructed labour (18.08\%) and hyperthermia $(16.9 \%)$ due to infectious diseases.

Conclusion: Most deaths in developing countries are preventable. Awareness of existing health facilities and need to attend them timely, hygiene in newly constructed and under construction areas and political will is the need of the hour.
\end{abstract}

Keywords: Intrauterine, Deaths, Hygiene, Maternal, Developing

\section{INTRODUCTION}

An intrauterine death of fetus is a cause of great stress for expecting mother and family. Several studies done in the past have shown reasons for this adverse event. ${ }^{1-6}$ Many of the reasons are preventable, and some of them are not preventable. Most causes of intrauterine deaths are common in all studies, though percentage differs. But study from different regions highlight some different causes, which are exclusive to that geographic region. ${ }^{1-}$ ${ }^{6,7,8}$ Most of such reasons are preventable.

Hence, the need for this study, which aims to determine the reasons for intrauterine deaths in rural and suburban Northern Indian population, and to see if possibly these deaths were preventable.

\section{METHODS}

This retrospective study was conducted in School of Medical Sciences and Research, a 500 bedded teaching hospital in Greater NOIDA. This hospital caters to a rural population and an ever expanding sub urban population. Large scale construction activities attract construction workers and supporting population. This population, even though living in urban areas, is exposed to unhygienic living conditions and lack of awareness of need of adequate medical support. Hence, a unique young population, representing growing India and developing world, is represented in this study.

All intrauterine deaths, occurring after 24 weeks of gestation and with fetus weighing more than $500 \mathrm{gm}$ were included in the study. Case records from Jan 2010 to April 2013 were studied and reasons for admission recorded. 
Age, gravidity, parity, antenatal care and unbooked pregnancy were noted. Any preexisting medical conditions, if present were recorded. Details of investigations done and causes of intrauterine deaths were studied and tabulated.

\section{RESULTS}

Total number of live births, including both normal and cesarean during the study period of Jan 2010 and April 2013 were 2380. Intrauterine deaths during the same period were $106(4 \%)$.

Out of these 106 intrauterine deaths, 88 of the patients were unbooked. They did not have any history of antenatal check up, and presented to the hospital after adverse symptoms or when they were unable to perceive fetal movements. Remaining 18 intrauterine deaths were in patients who had a regular antenatal follow up at the index hospital, or some other registered medical practitioner.

Forty of these deaths were in nullipara females, 28 in primipara and remaining 38 deaths were in multipara females. Thirty two of these nulliparous females were unbooked, where as 22 of the primiparous females were unbooked, and 34 multiparous females were unbooked and had no history of any antenatal checkup.

Eighty five patients were between age 21 to 30 and only 15 females were above age 30 .

Sixty two females had delivery before term, 40 deliveries were at term and only 4 were post-term. Two of these patients had preexisting diabetes, and were controlled on oral hypoglycemic. Both of them were multipara and had developed diabetes in the previous pregnancy. Remaining patients had no previous record of preexisting diseases.

The cause of intrauterine deaths was unknown in majority of patients $(26.41 \%)$. Other leading maternal causes of intrauterine death in our study were prolonged and obstructed labor $(18.86 \%)$, maternal hyperpyrexia due to infectious diseases (16.98\%), severe pre-eclampsia $(15.09 \%)$ and antepartum haemorrhage (7.54\%). Amongst fetal causes commonest was gross congenital anomaly contributing to $6.6 \%$ of all intrauterine deaths.

Table 1: Percentage of booked vs. unbooked pregnancies.

\begin{tabular}{|llll|}
\hline Parity & Booked & Unbooked & $\begin{array}{l}\text { Percentage } \\
\text { unbooked }\end{array}$ \\
\hline Nullipara & 8 & 32 & 80 \\
\hline Primipara & 6 & 22 & 78 \\
\hline Multipara & 4 & 34 & 90 \\
\hline
\end{tabular}

All reasons for intrauterine deaths were tabulated as per table 2 .

Distribution of weight of fetus at birth was as per table 3 .

Table 2: Causes of intrauterine deaths.

\begin{tabular}{|lll|}
\hline Cause & Number & Percentage \\
\hline Obstetric cholestasis & 1 & 0.94 \\
\hline Diabetes mellitus & 2 & 1.88 \\
\hline $\begin{array}{l}\text { Intrauterine growth } \\
\text { restriction }\end{array}$ & 2 & 1.88 \\
\hline Maternal infections & 4 & 3.77 \\
\hline $\begin{array}{l}\text { Gross congenital } \\
\text { anomaly }\end{array}$ & 7 & 6.60 \\
\hline $\begin{array}{l}\text { Antepartum } \\
\text { haemorrhage }\end{array}$ & 8 & 7.54 \\
\hline Severe preeclampsia & 16 & 15.09 \\
\hline Maternal hyperpyrexia & 18 & 16.98 \\
\hline $\begin{array}{l}\text { Prolonged \& } \\
\text { obstructed labor }\end{array}$ & 20 & 18.86 \\
\hline Unknown & 28 & 26.41 \\
\hline Total & 106 & 99.95 \\
\hline
\end{tabular}

Table 3: Birth weight of dead fetus at delivery.

\begin{tabular}{|lll|}
\hline Birth Weight (kgs) & Number & Percentage \\
\hline $0.5-1$ & 25 & 23.58 \\
\hline $1-1.5$ & 18 & 16.98 \\
\hline $1.5-2$ & 14 & 13.20 \\
\hline $2-2.5$ & 20 & 18.86 \\
\hline $2.5-3$ & 19 & 17.92 \\
\hline $3-3.5$ & 8 & 7.54 \\
\hline$>3.5$ & 2 & 1.88 \\
\hline
\end{tabular}

\section{DISCUSSION}

Universal antenatal care has been a long term goal of the successive Indian governments. ${ }^{9}$ Large scale budget allocations are made in the annual budgets for maternal and fetal safety in India and all other developing nations. ${ }^{10}$ Prevention of fetal and maternal deaths is an important indicator of health coverage of the population. $^{11}$

Developed countries have achieved low fetal and intrauterine mortality. ${ }^{12,13,14}$ This is due to high level of awareness for routine antenatal check up, and good 
medical facilities. Other reasons are hygienic lifestyle, as more money is spent on improving an already developed infrastructure. Hence, whatever intrauterine deaths that occur in these countries are mostly due to non preventable reasons or near misses. ${ }^{12}$

Developing countries like India have different problems. $^{15,16}$ Efforts by government have led to establishment of good hospitals at almost all parts of the country. Only the most rural and tribal areas are devoid of the medical coverage. But problems exist in awareness about the medical facilities and programs run by the government. Most of the population is not aware of the need for antenatal follow up. ${ }^{17,18}$ Advice by elders and untrained and unregistered medical practitioners only worsen the conditions. Infrastructure is being formed, hence hygiene is a problem. ${ }^{19}$ Large collection of stagnant water, lack of clean drinking water, non availability of hygienic toilet facilities all cause various problems in the females of child bearing age. These medical diseases often affect fetal health and lead to higher incidence of fetal mortality. Most of these deaths are potentially preventable.

Unbooked pregnancies resulting in intrauterine deaths were common in all parity females. Even multiparous females, who had previously delivered and were expected to utilize health care system in their next pregnancy, were mostly unbooked. This further highlights the lack of awareness of need to be part of medical coverage for a safe outcome of pregnancy. Even though most females were less than 30 years of age, many of them were multipara. Hence, most of them had close spaced pregnancy, inadequate nutrition and increased fetal mortality.

Most common reason for IUD was prolonged and obstructed labour in our study. ${ }^{20}$ This is different from other studies, where common reasons are antepartum hemorrhage, preeclampsia etc. ${ }^{1-8}$ Most of these patients were being handled at home, or with unregistered medical practitioners, were referred to the hospital once maternal exhaustion and prolonged labor had already harmed the fetus. These deaths were all easily preventable, had they initiated their labour in the hospital setting.

One unusual reason for large number of intrauterine fetal mortality was hyperthermia. Most common reason for hyperthermia was malaria. ${ }^{20,21}$ Malaria is known to cause intrauterine growth retardation by depleting placental transport of nutrients and cause placental changes in the trophoblast. Malaria further causes maternal anaemia, and hence can leads to intrauterine growth restriction. Hyperthermia further reduces transfer of nutrients and causes death of fetus.

Majority of intrauterine deaths were in fetus less than 2 $\mathrm{kg}$. This further reinforces the argument that maternal health and prevention of infections could have improved the duration of pregnancy and chances of survival of the fetus.

Most of these reasons are preventable. Routine and timely antenatal check-up can improve anemia, diagnose preventable and treatable diseases, and lead to more live births. $^{20}$ Delivery in a medical facility or registered medical practitioner can further ensure a safe normal vaginal delivery or timely Cesarean section in needful, keeping maternal and fetal wellbeing in mind.

Efforts by government have improved medical facilities. Emphasis should be made to improve awareness. That can improve antenatal checkups. This is difficult, but possible through medical camps in underdeveloped areas, and through radio and television media. It should be mandatory for health institutions to organize camps in nearby areas, and create awareness by interactions and deliverance.

Also efforts to improve hygiene in areas of growth, like towns with large scale construction activities should be started. Urgent need to identify such geographical areas, setting of units to look after hygiene and antenatal health of this population is the need of the hour, and can give us more productive and healthy population in the future.

\section{CONCLUSION}

Most common reasons for antepartum death of fetus are prolonged / obstructed labour and maternal infections causing febrile illness. Inadequate handling of patients in labour can be improved by creating awareness for hospital based deliveries. Infections, especially in areas under construction, need to be prevented by improving hygiene and sanitation. Awareness for early antenatal medical care will further reduce our incidence of intrauterine deaths.

Funding: None

Conflict of interest: None

Ethical approval: Approved by the institutional ethical committee

\section{REFERENCES}

1. Mmbaga BT, Lie RT, Olomi R, Mahande MJ, Olola $\mathrm{O}$, Daltveit AK. Causes of perinatal death at a tertiary care hospital in Northern Tanzania 20002010: a registry based study.BMC Pregnancy Childbirth. 2012 Dec 2;12:139.

2. Shrestha M, Manandhar DS, Dhakal S, Nepal N. Two year audit of perinatal mortality at Kathmandu Medical College Teaching Hospital. Kathmandu Univ Med J (KUMJ). 2006 Apr-Jun;4(2):176-81.

3. Rackham O, Paize F, Weindling AM. Cause of death in infants of women with pregestational diabetes mellitus and the relationship with glycemic 
control. Postgrad Med. 2009 Jul;121(4):26-32. doi: 10.3810/pgm.2009.07.2026.

4. Lawn JE, Kinney M, Lee AC, Chopra M, Donnay F, Paul VK, Bhutta ZA, Bateman M, Darmstadt GL. Reducing intrapartum-related deaths and disability: can the health system deliver? Int J Gynaecol Obstet. 2009 Oct;107 Suppl 1:S123-40, S140-2.

5. Gordon A, Raynes-Greenow C, McGeechan K, Morris J, Jeffery H. Risk factors for antepartum stillbirth and the influence of maternal age in New South Wales Australia: a population based study. BMC Pregnancy Childbirth. 2013 Jan 16;13:12.

6. Korejo R, Bhutta S, Noorani KJ, Bhutta ZA. An audit and trends of perinatal mortality at the Jinnah Postgraduate Medical Centre, Karachi. J Pak Med Assoc. 2007 Apr;57(4):168-72.

7. Stillbirth Collaborative Research Network Writing Group. Causes of death among stillbirths. JAMA. 2011 Dec 14;306(22):2459-68.

8. Wall SN, Lee AC, Carlo W, Goldenberg R, Niermeyer S, Darmstadt GL, Keenan W, Bhutta ZA, Perlman J, Lawn JE. Reducing intrapartum-related neonatal deaths in low- and middle-income countries-what works? Semin Perinatol. 2010 Dec;34(6):395-407.

9. Gupta SK, Pal DK, Tiwari R, Garg R, Shrivastava AK, Sarawagi R, Patil R, Agarwal L, Gupta P, Lahariya C. Impact of Janani Suraksha Yojana on institutional delivery rate and maternal morbidity and mortality: an observational study in India. J Health Popul Nutr. 2012 Dec;30(4):464-71.

10. Lim SS, Dandona L, Hoisington JA, James SL, Hogan MC, Gakidou E. India's Janani Suraksha Yojana, a conditional cash transfer programme to increase births in health facilities: an impact evaluation. Lancet. 2010 Jun 5;375(9730):2009-23.

11. Bhakoo ON, Kumar P. Current challenges and future prospects of neonatal care in India. Indian J Pediatr. 2013 Jan;80(1):39-49.

12. King JC. Strategies to reduce maternal mortality in developed countries. Curr Opin Obstet Gynecol. 2013 Apr; 25(2):117-23.

13. Kim D, Saada A. The social determinants of infant mortality and birth outcomes in Western developed nations: a cross-country systematic review. Int $\mathbf{J}$
Environ Res Public Health. 2013 Jun 5;10(6):2296335.

14. deGraaf JP, Steegers EA, Bonsel GJ. Inequalities in perinatal and maternal health. Curr Opin Obstet Gynecol. 2013 Apr;25(2):98-108.

15. Mason JB, Saldanha LS, Ramakrishnan U, Lowe A, Noznesky EA, Girard AW, McFarland DA, Martorell R. Opportunities for improving maternal nutrition and birth outcomes: synthesis of country experiences. Food Nutr Bull. 2012 Jun;33(2 Suppl):S104-37. Review.

16. Jain T, Garg S, Singh MM, Kaushik A, Batra S, Gupta VK, Ingle GK. Antepartum morbidities and health seeking behaviour among women in an urban slum of Delhi. J Indian Med Assoc. 2011 May;109(5):315-7.

17. George A. Persistence of high maternal mortality in Koppal district, Karnataka, India: observed service delivery constraints..Reprod Health Matters. 2007 Nov;15(30):91-102.

18. Paul VK, Sachdev HS, Mavalankar D, Ramachandran P, Sankar MJ, Bhandari N, Sreenivas V, Sundararaman T, Govil D, Osrin D, Kirkwood B. Reproductive health, and child health and nutrition in India: meeting the challenge. Lancet. 2011 Jan 22;377(9762):332-49.

19. Crook N, Malaker CR. Child mortality in new industrial localities and opportunities for change: a survey in an Indian steel town. Health Transit Rev. 1992 Oct;2(2):165-76.

20. McClure EM, Saleem S, Pasha O, Goldenberg RL. Stillbirth in developing countries: a review of causes, risk factors and prevention strategies. J Matern Fetal Neonatal Med. 2009 Mar;22(3):18390.

21. Wylie BJ, Hashmi AH, Singh N, Singh MP, Tuchman J, Hussain M, Sabin L, Yeboah-Antwi K, Banerjee C, Brooks MI, Desai M, Udhayakumar V, Macleod WB, Dash AP, Hamer DH. Availability and utilization of malaria prevention strategies in pregnancy in eastern India. BMC Public Health. 2010 Sep 17;10:557. doi: 10.1186/1471-2458-10557.

DOI: $10.5455 / 2320-1770$. ijrcog20131223

Cite this article as: Gupta N, Chutani N.

Intrauterine deaths: challenges faced in developing countries. Int J Reprod Contracept Obstet Gynecol 2013;2:607-10. 